O nikczemności żartów i śmiechu świeckiego, czyli płacz Heraklita i śmiech Demokryta chrześcijańskiego $\mathrm{w}$ piśmiennictwie ascetyczno-medytacyjnym doby potrydenckiej w Polsce

Maria Wichowa 
nAP7S Seria XIV 2008

\author{
Maria Wichowa
}

\title{
O nikczemności żartów i śmiechu świeckiego, czyli płacz Heraklita i śmiech Demokryta chrześcijańskiego w piśmiennictwie ascetyczno- medytacyjnym doby potrydenckiej w Polsce
}

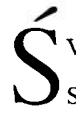
więty Kościół Powszechny już od zarania swych dziejów próbował ustosunkować się do kwestii, czy chrześcijaninowi przystoi śmiać się bez naruszenia jego godności. Jedni uczeni, filozofowie i teologowie nakazywali rygorystycznie odrzucić rozrywkę, bo wywołuje ona nieprzystojną wesołość, inni tolerancyjnie i życzliwie przyznawali człowiekowi prawo do śmiechu. Ta ambiwalencja znalazła wyraz w dziele Cezarego Ripy Ikonologia ${ }^{1}$, w którym autor przedstawił dwa wizerunki śmiechu i ich wykładnię alegoryczno-symboliczną.

Pierwsza propozycja to pokazanie pięknego, pewnego powabu młodzieńca w kolorowej, pstrokatej odzieży - a więc jakiegoś niepoważnego lekkoducha — na zielonej lące pełnej kwiatów, z wieńcem z rozwijających się róż na głowie. Wiek ma tu symboliczne znaczenie, gdyż w młodości człowiek ma w sobie dużo radości życia, i wtedy najczęściej jest mu do śmiechu, bo wesołość prawie go nie opuszcza. Śmiech jest synem wesołości. Kojarzy się z pięknem, miłymi przeżyciami, symbiozą człowieka z naturą. Stąd „zwykło się mówić, że łąki się śmieją, gdy zaczynają się zielenić, kwiaty zaś — gdy rozkwitają"2.

$\mathrm{Na}$ drugim obrazie ma również być przedstawiony młodzieniec, ubrany w strój symbolizujący beztroskę, skłonność do zabawy. Albowiem ma to być ubiór zielony

\footnotetext{
${ }^{1}$ Zob. C. Ripa, Ikonologia, tł. I. Kania, Kraków 2002. Autor żył w latach 1560-1625, I wyd. dzieła: 1603, nast. $1618,1630$.

2 Ibidem, s. 383.
} 
w kolorowe kwiaty, dopelniony stosownym nakryciem głowy, czyli kapelusikiem ozdobionym różnorodnymi piórami, które oznaczają „płochość i swawolność, z czego rodzi się nieumiarkowany śmiech"3. Pojawia się tu pewien odcień nagany czy deprecjonowania śmiechu, w sytuacji, gdy jest on nieumiarkowany. Dla poparcia tej tezy Ripa przytoczył słowa Mędrca: Risus abundat in ore stultorum (obfity śmiech pojawia się na ustach głupców). Idzie o przypowieści Salomonowe z biblijnej Ksiegi przystów $(10,23 ; 14,9 ; 14,13)^{4}$, zacytowane niezbyt ściśle, a raczej streszczone w nowo utworzonej sentencji, zręcznie „przykrojonej” do kontekstu, zaostrzającej stanowisko oryginału wobec przedstawianej kwestii. Śmiech zostaje „poniżony”, zdeprecjonowany, jego rola w życiu człowieka zmarginalizowana, znaczenie jego w stosunku do poglądów wypracowanych przez pisarzy antycznych odwrócone.

Wedlug Horacego na przykład, poeta ludens powinien bowiem ridentem dicere ve$r u^{5}{ }^{5}$ ( $\mathrm{z}$ uśmiechem mówić prawdę). Idzie dosłownie o to, aby „mówić uśmiechającą się prawdę", czyli umieszczać ją w lekkich, żartobliwych dziełach, na podobieństwo nauczycieli, zachęcających małe dzieci do nauki częstowaniem słodyczami. Horacy zwrócił uwagę na jeszcze jeden dobroczynny aspekt śmiechu, pisząc słowa: Ridiculum acri / fortius et melius magnas plerumque secat res ${ }^{6}$, czyli że śmiech zwykle ucina wszelkie sprawy mocniej i lepiej niż ostre powiedzenie. W średniowieczu i kolejnych epokach, zalecających wygaszenie wszystkich pragnień ziemskich jako otwarcie drogi do nie$\mathrm{ba}$, surowa asceza stanowiła priorytet $\mathrm{w}$ działaniach człowieka pobożnego. Nie było do śmiechu tym, którzy mieli poczucie, że w imię wyższych wartości powinni się odwrócić od świata i wzgardzić nim, koncentrować swoją uwagę na rzeczach i sprawach ważnych, poddawać się licznym próbom, aby doskonalić swą duchowość, pracować nad własnym zbawieniem? ${ }^{7}$.

Wspomniane na wstępie tych rozważań ambiwalentne podejście do śmiechu było szczególne ważne na terenie Kościoła, który nie był w tej sprawie konsekwentny. Wielu teologów-ascetów opowiadało się za rygorystycznym potępieniem śmiechu, wielu znów uważało, że należy go tolerować. Ci, którzy byli zwolennikami napiętnowania śmiechu, zakazywali go. Powoływano się przy tym na zalecenia św. Pawła, zawarte w Liście do Efezjan (5,3-4):

\footnotetext{
${ }^{3}$ Ibidem.

${ }^{4}$ Ksiega Przysłów (Przypouieści Salomonoue) 10,23: „Głupi jakoby śmiechem czyni niecnotę, ale mądrością jest mężowi baczność”; 14,9: „Głupi będzie się śmiał z grzechu, a między sprawiedliwymi będzie mieszkała łaska”; 14,13: „Śmiech będzie zmieszan z żałością, a koniec wesela smutek posiada” (tł. J. Wujek).

${ }^{5}$ Horacy, Satyry I 1, 24.

${ }^{6}$ Ibidem, I 10, 14-15.

${ }^{7}$ Pisał o tym Jean Delumeau, Grzech i strach. Poczucie winy w kulturze Zachodu XIII-XIV w., th. A. Szymanowski, Warszawa 1994, rozdz. Rzesza potepiona i system grzechu.
} 
A porubstwo i wszelka nieczystość, abo lakomstwo niechaj nie będzie ani pomieniono między wami, jako świętym przystoi, abo sprosność, abo głupia mowa, abo żartowanie, które do rzeczy nie należy $[\ldots]^{8}$.

Uczeni wzięli ten temat na warsztat'. Pisał o tym obszernie Klemens z Aleksandrii. Jan Chryzostom był przekonany, że Chrystus nigdy się nie śmiał. Św. Efrem Syryjczyk, doktor Kościoła, opracował specjalnie rozważania dla zakonników, skierowane przeciwko wesołości. Podobne stanowisko zajmowali św. Bazyli Wielki i św. Jan Kasjan. Bardzo rygorystycznie ujmował tę kwestię św. Benedykt z Nursji: „słów obscenicznych, wstrętnych i wywołujących śmiech unikajmy jak jadu żmii”10. Zdanie to stało się obowiązującą w średniowieczu dyrektywą. Ponownie zagadnienie dopuszczalności śmiechu rozpatrywali teologowie w XII w. i nieco zlagodzili stanowisko. Mianowicie Jan z Salisbury, średniowieczny pisarz, humanista-cyceronianin i uczony, biskup Chartres, uważal, że „umiarkowana wesołość” nie jest czymś złym, byle tylko człowiek w niej uczestniczący zachowywal się przyzwoicie i roztropnie. Zastanawiał się też nad tym, czy śmiech jest częścią natury ludzkiej, czy Chrystus, Bóg-Człowiek, uczestnicząc w ludzkiej naturze, śmiał się kiedykolwiek? Może jest jakiś szczególny rodzaj Boskiej wesołości? Rygorystyczne odrzucenie wesołości postulowała kontrreformacja.

Niechęć, uprzedzenie czy wręcz wrogość do rozrywek rozpowszechniali duszpasterze w kazaniach, głosząc marność człowieka, wzbudzając strach przed potępieniem, uświadamiając konieczność odbywania pokuty i nieroztropność tych, którzy, jak to ujął Augustyn Kochański - tlumacz traktatu Diega de Estella $O$ wzgardzie świata i próżności jego troje ksiag ${ }^{11}$, „pokutę odwłaczają” do momentu śmierci. Księża wywoływali wręcz przerażenie wiernych, gdy uświadamiali im konsekwencje pozostawania w stanie grzechu śmiertelnego i surowość sądu Bożego. Pobożni chrześcijanie żyli w obawie przez skazaniem ich na kary piekielne, przed wiecznym zatraceniem duszy. Przejęcie się głoszonymi przez kaznodziejów tego typu wizjami powodowało u osób objętych ich opieką duchową męki, cierpienie, udręki psychiczne, upokarzanie się grzesznika, który wskutek wiary w swoją marność i nędzę bywał pozbawiony poczucia własnej godności i spokoju wewnętrznego. Pozostawało już tylko płakać nad własną niedoskonałością, patrzeć na człowieka jak na zbrodniarza, który w ten sposób bywał pozbawiony poczucia własnej wartości, i lękał się, że stanie przed strasznym Bożym trybunałem i zostanie potępiony.

` Tł. J. Wujek; przekład w Biblii Tysiąclecia: „O nierządzie zaś i wszelkiej nieczystości albo chciwości niechaj nawet mowy nie będzie wśród was, jak przystoi świętym, ani o tym, co haniebne, ani o niedorzecznym gadaniu lub nieprzyzwoitych żartach, bo to wszystko jest niestosowne".

${ }^{9}$ Kwestię tę omawiam za: E. R. Curtius, Literatura europejska i łacińska średniouiecza, tł. i opr. A. Borowski, Kraków 1997.

${ }^{10}$ Cyt. za: ibidem, s. 431.

${ }^{11}$ Diego de Estella, O wzgardzie świata i próżności jego troje ksiag..., t1. A. Kochański, Poznań 1611, drukarnia Jana Wolraba [na k. tyt. nazwisko autora: Dydak Stella]. 
Duszpasterze średniowieczni i kontynuatorzy ich nauki o marności ludzkiej istoty w następnych epokach, aż po późny barok włącznie, pouczali, że jednak droga do zbawienia jest otwarta dla tych, którzy świadomie ćwiczą się w upokarzaniu samego siebie, w umartwianiu. Człowiek sam sobie nakładał kary, według swojego mniemania określając, czy są stosowne do rangi jego występków. Według własnej oceny asceta łączył się w zadawanym sobie cierpieniu z Chrystusem, przeżywając męki duchowe za grzechy własne i bliźnich, wraz z nim zamieszkujących ten „nieświetny świat”, stanowiący królestwo grzechu i szatana. Ponieważ cierpienia te były skutkiem miłości do Zbawiciela, dzięki niej też bywały przezwyciężane. Życie ascetyczne bylo udziałem wielu wybitnych ludzi tamtych wieków, dawało im radość współcierpienia z Bogiem-Człowiekiem. Parę istotnych przykładów tego typu myślenia przytoczył w przywoływanej już tutaj pracy Jean Delumeau:

Reguła świętego Benedykta żąda od mnicha, by ten pojmował swoje życie jako „dzielenie cierpień” z Jezusem. Niechaj więc niczego nie przedkłada nad miłość Chrystusa. Zniechęcenia i pokusy rozbiją się o tę skałę. Święty Jan od Krzyża zapewnia, że „męki i udręczenia przyjęte dla Boga są niby drogocenne perły, co im większe, tym są kosztowniejsze i rozbudzają miłość w tym, który je otrzymuje, do tego, który je daje"12.

Średniowieczna pedagogika religijna posuwała się do skrajności. Podawało najbardziej nieosiągalne postawy jako wzorce godne naśladowania. Powszechnie zalecano medytacje o wzgardzie świata i nędzy człowieka, zakazywano żartów i śmiechu.

[...] uśmiechnięty święty Wincenty żąda od sióstr szarytek, by „nie patrzyły na piękne rzeczy, kiedy skłania do tego ciekawość” i umartwiały... uszy, które rozkoszują się słuchaniem pieśni, muzyki, pochwał, jakimi się [je] obdarza, śpiewu ptaków. Uszy radują się takimi rzeczami, ale trzeba się umartwiać i od tych rzeczy uciekać, nie zaś ich poszukiwać ${ }^{13}$.

Penitenci karmieni taką strawą duchową całkowicie wyrzekali się wszelkich zainteresowań powabami świata. W XV w. w ich środowiskach „śmiech zamarl” całkowicie, wydzierano $z$ siebie radość życia, popadano $w$ przygnębienie i melancholię ${ }^{14}$. Potrzebni byli rozsądni przewodnicy duchowi, umiejętnie kierujący pracą wiernych nad doskonaleniem się wewnętrznym, ograniczający owe umartwienia cielesne i du-

\footnotetext{
${ }^{12}$ J. Delumeau, Grzech i strach..., op. cit., s. 447.

${ }_{13}$ Ibidem, s. 450.

${ }^{14}$ Pisał o tym Johan Huizinga, Jesień średniowiecza, tł. T. Brzostowski, wst. H. Barycz, posł. S. Herbst, t. 1, Warszawa 1967, s. 65 i nast.
} 
chowe, w tym wyeliminowanie rozrywek, odrzucenie śmiechu, który nie przystoi pobożnemu człowiekowi. Duże zasługi ma tu święty Ignacy Loyola, który swego czasu praktykowal ascetyczne umartwianie, bo sądzil, że w ten sposób uraduje Pana Boga ${ }^{15}$, a także odpokutuje za swoje grzechy, ale po latach wypracował innego rodzaju metodę doskonalenia się.

W jego Autobiografii zamieszczona jest informacja, że

aż do dwudziestego siódmego roku życia był człowiekiem oddanym marnościom tego świata. Szczególniejsze upodobanie znajdował w ćwiczeniach rycerskich, żywiąc wielkie i próżne pragnienie zdobycia sławy ${ }^{16}$.

Źródła podają, że zakosztował w pełni powabów świata doczesnego, oddawał się grom, awanturom, nie stronił od kobiet, a przynajmniej po rycersku adorowal damy serca, a na pewno księżniczkę Katarzynę, siostrę Karola V, która w przyszłości jako żona króla Portugalii Jana III zachowała pamięć i życzliwość dla swego adoratora i wspierała wraz z mężem Towarzystwo Jezusowe ${ }^{17}$. Zakosztował więc światowych rozkoszy, które potem uznał za marność i próżność. Napisał po latach Ćwiczenia duchowne, podręcznik mający być pomocą dla tych, którzy narzucili sobie dyscyplinę wewnętrzną, zdecydowali się na drodze medytacji dążyć do chrześcijańskiej doskonałości, do zbawienia. Św. Ignacy kierował swoje dzieło do bezimiennych odbiorców, do osób nieznanych, stąd uważal, że zalecane w podręczniku ćwiczenia powinny być prowadzone pod nadzorem kierownika duchownego, który by brał pod uwagę indywidualność, temperament, oblicze intelektualne tego, kto prowadzi medytację, bo ma ona wywołać bardzo osobiste przeżycie modlitwy, rozmowy z Bogiem. Praca nad propagowaniem duchowości ascetyczno-mistycznej była celem działalności jezuitów, zwalczających w ten sposób reformację.

Jeden z nich, ks. Marcin Laterna (1552-1598), doktor teologii Akademii Wileńskiej, kaznodzieja i spowiednik króla Stefana Batorego, a potem Zygmunta III (objął urząd po Piotrze Skardze), napisal bardzo popularny modlitewnik (od 1585 roku do końca XVIII wieku miał on 25 wydań) o konceptystycznym tytule Harfa duchowna. Autor tłumaczył w przedmowie do tego dzieła, jak wierni powinni dobierać sobie lektury, aby wspierały one rozwój i pogłębienie pobożności, postępy na drodze dochodzenia do chrześcijańskiej doskonałości. Uświadamiał czytelnikom, że aby nie dawać powodu do narzekań kaznodziejom i moralistom, trzeba spożywać odpowiednią strawę du-

15 Zob. św. Ignacy Loyola, Pisma wybrane, t. 1, Kraków 1968, s. 184.

${ }^{16}$ Cyt. za: J. Lacouture, Jezuici, t. 1: Zdobywcy, tł. H. Lubicz-Trawkowska, Warszawa 1998. Autobiografia dostępna jest po polsku w wydaniu: L. Gonçalves da Camara, Memoriale czyli diariusz o św. Ignacym Loyoli 1555, tł. M. Bednarz, Kraków 1995.

17 Zob. J. Lacouture, Jezuici, op. cit. , s. 16. 
chową. Jezuicki autor zaleca czytanie żywotów świętych, zbiorów kazań zawierających wykłady Ewangelii ułożone według kalendarza kościelnego, duchowne „zwierciadła”, przewodniki, „wizerunki”, „raje duszne”. Wyraża nadzieję, że z biegiem czasu takich książek będzie coraz więcej. Założyciel zakonu i jego wybitni następcy z satysfakcją by czytali opinię ojca Marcina na temat rozrywek, jakim mogą się oddawać chrześcijanie podczas lektury poczytnych wówczas dzieł. Laterna dokonał przeglądu dostępnej na rynku czytelniczym literatury religijnej i ocenił jej wartość dla pracy chrześcijanina nad pogłębianiem pobożności. Uznał, że stan tego piśmiennictwa nie cieszy ani czytelników, ani kapłanów. Dostępne są publikacje innowiercze, jak na przykład katechizm polski zwingliański, ,jako cierniowy jaki wianek uwity i jakąkolwiek muzyką ozdobiony" - jak mówi o nim z cierpkim humorem jezuicki intelektualista. Nie zadowalają go druczki zawierające „krótkie modlitwy niektóre”, rzekomo zalecające cześć Pana Boga, lecz w nich „najdziesz niemało rzeczy, wierze powszechnej przeciwnych”. Wspomina osobne wydanie Psalmów z Biblii brzeskiej, rozpowszechnionych jakoby dla nabożeństwa chrześcijańskiego człowieka, bo tam „często katolickiego wykładu chybil tłumacz, tak też fałszem i wykręty narabiał, czego dowieść nietrudno".

Wcale nie jest lepiej, gdy ksiądz Laterna ocenia stan poradników duchownych i modlitewników katolickich. Stare „hortulusy” nie spełniają oczekiwań chrześcijańskiego czytelnika doby potrydenckiej, bo choć z pewnością Pan Bóg autorów za ich trud wynagrodzi, to trudno uznać, że mogą one dalej służyć pomnażaniu pobożności katolickiej. Wiadomo na pewno, że „niektóre niepewnymi odpusty, drugie opacznym nabożeństwem i inszym drobniejszym proszkiem nieco się przykurzyły, a niektóre też prze krótkość, niemało rzeczy tym czasom potrzebnych nie dołożyły". Autor Harfy duchownej z odcieniem nagany mówi o tym, że zaniedbano opracowanie pożytecznych modlitewników, podczas gdy całkiem zadowalający jest stan piśmiennictwa naukowego. Napisano dobre podręczniki gramatyki i dialektyki, wystarczająco dużo powstało przekładów z literatur antycznych, wiele wnikliwych komentarzy do dziel klasycznych, wiele parafraz utworów wybitnych poetów. Najgorsze jest to, że rynek książkowy jest zasypywany wszelkiego rodzaju tandetą, która służy czystej rozrywce „wiernych sług Bożych”. Książki te „gorzej niż strzały dusze ludzkie obraźliwie przenikają”, „do oczu, uszu i rąk ludzkich są podawane”. W tej grupie piśmiennictwa o charakterze ludycznym jezuicki moralista piętnuje istnienie poczytnych „Marchułtów zmyślonych, obraźliwych fabul, sprosnych kunsztów i nie do końca uczciwych fraszek, zwierciadł, Fortun i snów w Polszcze wydrukowanych".

Laterna odrzuca więc wszystko, co służy żartom i śmiechowi świeckiemu. Jak widać ze sporządzonego przez niego rejestru, piśmiennictwo ludyczne było dobrze rozwinięte. Nie aprobuje jezuicki moralista tej grupy dzieł, które reprezentuje powieść błazeńska Rozmowy, które miat król Salomon mąry z Marchottem grubym a sprosnym, a wszakoż, jako o nim poviedaja, barzo wymownym, z figurami i gadkami śmiesznymi, tłumaczona $z$ łaciny przez Jana z Koszyczek (wyd. Kraków 1521). Nie akceptuje też 
„fabul” zmyślonych - zapewne ma na uwadze Fabuty Ezopowe abo przypowieści (druk z początku XVII w.), pisane prozą, albo wcześniejsze opracowanie poetyckie $\dot{Z}$ ywot Ezopa Fryga, mędrca obyczajnego z przypowieściami jego Biernata z Lublina (wyd. Kraków 1578), choć większą rolę w popularyzacji motywów rozrywkowych odegral tekst późniejszy, prozaiczny, bo dzieło Biernata dostało się na indeks ksiąg zakazanych. Do tej grupy zaliczyć też należy przeróbki bajek Fedrusa i Babriosa. Ksiądz Laterna, przeciwnik żartów i śmiechu świeckiego, dopatruje się w tej grupie utworów treści niemoralnych, obraźliwych. Fraszki akceptuje tylko po części; jak się wydaje, idzie mu o fraszki poważne, $\mathrm{z}$ morałem, zaś wesołe, żartobliwe, a tym bardziej erotyczne, odrzuca. „Sprośne kunszty” to być może różnego rodzaju literackie zabawy językowe $\mathrm{z}$ kręgu poesis artificiosa, o charakterze ludycznym i miłosnym. Obok fraszek sytuują się facecje - krótkie opowiadania komiczne ujęte prozą, anegdoty, krotochwile, dykteryjki, "gadki” czyli zagadki pisane dla wzbudzenia czystego śmiechu. Wymieniony „Fortun” to zapewne Historyja o Fortunacie czyli przekład z języka niemieckiego średniowiecznego romansu, $\mathrm{w}$ istocie rzeczy pierwsza w literaturze polskiej powieść przygodowa, wydana w Krakowie około 1570 roku. Dzieło nieznanego tłumacza nosi cechy romansu rycerskiego i awanturniczego zarazem. „Zwierciadła”, które dostały się na listę Laterny, to liczna grupa traktatów z obszaru literatury parenetycznej, obejmująca utwory zwane „zwierciadłami”, ,wizerunkami”, „żywotami”, przedstawiające wzorce osobowe do naśladowania, wyidealizowane wizerunki bohaterów reprezentujących określony stan (dworzanin, ziemianin, senator, rycerz). Napiętnowane zostały także „sny” czyli, jak wolno się domyślać, senniki (książki z obszaru literatury popularnej) zawierające tłumaczenia snów, pomagające w ustalaniu, jaką prognozę na przyszłość zapowiada analizowany sen.

Autor Harfy... powołuje się na humanistyczną zasadę varietas delectat, który to zwrot thumaczy swobodnie wierszem w następującym brzmieniu: „Człowiek skłonny do nowości, rad się kocha w rozliczności”. Jednak sentencja ta nie odnosi się do napiętnowanej grupy tekstów zawierających żarty, skłaniających do beztroskiej rozrywki, lecz do piśmiennictwa religijnego. Uczony jezuita dostrzegł poważną niszę na rynku wydawniczym i opracował książkę do nabożeństwa, zawierającą bardzo bogatą ofertę tekstów modlitewnych i komentarze do nich, „nauki, które się w tych rzeczach zamykają", w tym celu, aby pobudzić refleksję religijną wiernych, aby pomóc pogłębić ich medytacje, wzniecić i zintensyfikować miłość do Boga. Wileński kaznodzieja, idąc z duchem swoich czasów i realizując nakazy swoich przełożonych, nawołuje do radykalnego odrzucenia rozrywek i śmiechu świeckiego, skupienia się na modlitwie i medytacji, na uprawianiu ćwiczeń duchowych zalecanych przez założyciela zakonu, a rozpowszechnionych w całej Europie jako sposób doskonalenia się wewnętrznego katolików.

W Polsce pojawiła się fala edycji i tłumaczeń pism autorów ascetyczno-mistycznych. Pod koniec wieku XVII zostały opublikowane dwa przeklady francuskiego księ- 
dza Piotra Besseusza (Pierre de Besse), wybitnego kaznodziei i pisarza (1567-1639). Był on autorem cyklu kazań, wydawcą Biblii łacińsko-francuskiej, ilustrowanej parafrazy Psatterza Dawidowego oraz szkiców: Heraclite chrétien (1612) i Democrite chrétien (1615). Dwa ostatnie wymienione dzieła ukazały się po polsku, w przekładzie bliżej nieznanego księdza Mateusza Ignacego Kuligowskiego ${ }^{18}$. Ptacz Heraklita miał chyba dwa wydania, bo notowany jest przez bibliografie pod różniącymi się zasadniczo tytułami: Heraklita chrzésijańskiego albo grzesznika pokutujacego lamenta (Warszawa 1694, drukarnia pijarów) i Heraklit chrześcijański ks. Piotra Besseusza ${ }^{19} z$ tacińskiego tekstu przez Mateusza Ignacego Kuligowskiego... wierszem polskim wytożony, to jest lament grzesznika pokutujacego $i$ do druku dla pospolitego pożytku podany w roku $1694 \mathrm{w}$ Warszawie, w drukarni pijarów. Natomiast drugi utwór, niesłusznie zaliczany do twórczości oryginalnej, nosi tytul Demokryt śmieszny albo śmiech życia ludzkiego rozdzielony, i był wydany w roku 1699 w Wilnie u jezuitów.

Dzieła Besseusza nawiązywały do bardzo popularnego w baroku tematu: Heraklita — filozofa płaczącego i Demokryta — filozofa śmiejącego się. „Łzy Heraklitowe” wymienil już Jan Kochanowski w Trenach jako symbol cierpienia i płaczu. Filozofów tych często zestawiano na zasadzie przeciwieństwa. Tak potraktował ich ksiądz Benedykt Chmielowski w trzecim tomie Nowych Aten, w rozdziale Abrys żywy nieżyuych (żywa pagina uściśla informację wyrażoną w tytule konceptem, że jest to Katalog osób wiadomości o sobie godnych):

Democritus z Abdery, miasta Tracyi, filozof, astrolog, czarnoksiężnik, wielki peregrynant, natury scrutator [badacz], dlatego sam się oślepił. Ojciec jego tak bogaty był, że Kserksesa, króla perskiego wojsko wielkie lautissime [przewspaniale] utraktował. Ze wszystkich akcyi ludzkich, jakby nierozumne były, zawsze się śmial, stąd Democritus ridens [Demokryt śmiejący się]. Temu przeciwny byl Heraclitus efeski filozof, któremu dali epitheton Tenebricosus [ciemny, mroczny], iż bardzo obscure [ciemno, niejasno] pisał. $\mathrm{Z}$ domu ilekroć wychodził, rozpłakal się, stąd Heraclitusflens [Heraklit płaczący]. W starości w puchlinę zapadł, i powiadają, od psów rozszarpany. Piszą o nim, że żadnego nie miał mistrza, ale $\mathrm{z}$ własnej aplikacyi doszedł nauki; drudzy twierdzą, iż Ksenokratesa miał preceptora. Żył za czasów ostatniego króla perskiego Dariusza $\mathrm{O}$ tych obuch Ovenus następujące wiersze napisal:

${ }^{18}$ Zob. biogramy w: Polski stownik biograficzny, t. 16, Wrocław 1992 (aut. P. Buchwald-Pelcowa); Dawni pisarze polscy od początków piśmiennictwa do Młodej Polski. Przewodnik biograficzny i bibliograficzny, t. 2, Warszawa 2001.

${ }_{19}$ Zob. Encyklopedia katolicka, t. 2, Lublin 1985, s. 330. 
Ille nihil nisi risit, et iste nihil nisi flevit, Istene ridendus, flendus an ille magis?

Item:

\author{
Deflerit mores, si viveret, Heraclitus, \\ Nostraque rideret tempora Democritus ${ }^{20}$.
}

Historycy sztuki dopatrują sie występowania tej pary filozofów na obrazie Rembrandta Śmiejacy się, znany jest wizerunek Heraklita w Szkole ateńskiej (1509-1512) Rafaela Santi; Donato Bramante namalował fresk Heraklit i Demokryt ${ }^{22}$.

Wizerunki płaczącego i śmiejącego się filozofa w świadomości potocznej kształtowały się zapewne przez stulecia, a ich źródła należy dopatrywać się w wiadomościach na ich temat przekazanych przez Diogenesa Laertiosa ${ }^{23}$. O Heraklicie można się z tego dzieła dowiedzieć, że „wiódl żywot pełen cierpień”, był wyniosły, ludzi traktował pogardliwie, że opuścił Efez i wybrał samotne życie w górach, co jednak nie wyszło mu na zdrowie, bo nabawił się puchliny wodnej, która stała się przyczyną jego śmierci, że mówił zagadkami i miał skłonności do melancholii. Demokryt w świetle tego źródła był wybitnym uczonym, bardzo pracowitym, skupionym na działalności twórczej. Mieszkał w małym domku z ogrodem, w którym się zamykał, całkowicie pogrążając się w myślach. Głosił, że najwyższym celem człowieka jest pogoda ducha, czyli stan spokoju i równowagi wewnętrznej, uwolnienie się od strachu. Cenił ciszę i harmonię wewnętrzną, gdyż wtedy mógł się calkowicie oddać pracy naukowej. Zapewne dla pogodnego usposobienia nazywano go „śmiejącym się filozofem".

Demokryt śmieszny Besseusza-Kuligowskiego nie przypomina swego greckiego antenata, śmieje się śmiechem grzesznika-moralisty.

Więc śmiech człowiek, śmiech życie, śmiech jest jego chwała, Śmiech praca bez bojaźni Bożej pozostała.

${ }^{20}$ B. Chmielowski, Nowe Ateny..., t. 3, Lwów 1754, s. 620. Autor słynnej encyklopedii cytuje tu w oryginale epigramy Johna Owena (Ioannes Audoenus, 1564-1622): w całości dwuwiersz Democritus et Heraclitus (Epigrammata II 46) i początek Omnia vanitas (Epigrammata III 146, w. 1-2; całość: 6 w.); $\mathrm{w}$ wolnym przekładzie brzmiące:

Ten tylko się śmial, ów tylko płakał.

Który większy: ów roześmiany czy tamten płaczący?

Opłakałby, gdyby żył, Heraklit nasze obyczaje,

I śmiałby się Demokryt z naszych czasów.

${ }_{21}^{21}$ Zob. J. Białostocki, Symbole i obrazy w śuiecie sztuki, t. 1, Warszawa 1982, s. 317.

${ }_{22}$ Zob. ibidem, t. 2, ryc. 59 i 194.

${ }_{23}$ Zob. Diogenes Laertios, Żywoty i poglady słynnych filozofów, tł. I. Krońska, K. Leśniak, W. Olszewski, opr. I. Krońska, wst. K. Leśniak, Warszawa 1982. 
A ja patrząc na ludzkie o świecie staranie,

Śmiech mam: ha! ha! i będę, póki mi tchu stanie [s. 312].

Śmiech Demokryta chrześcijańskiego rozlega się i wtedy, gdy „ciała rozkosz zaślepia lubieżnych”, bo „śmiech u potomnych mieć będę ciała słudzy” [s. 36]. Śmiech z tego świata pojawia się podczas refleksji nad żywotem ludzkim, który ,jest nic, i śmiech”, i wówczas, gdy patrzy się na ludzkie wady:

Tedy ja z takich mam śmiech, którzy niefrasunkiem

Ani płacą życie swe, lecz stracają trunkiem.

Zaczym nie czyńmy śmiechu narodom postronnym,

Takim nałogiem naszym do napojów skłonnym [s. 58].

Wiele ma powodów do śmiechu Demokryt chrześcijański. Jest to śmiech podbarwiony ironią, groteską i sarkazmem moralisty, który dobrze zna grzeszną naturę człowieka, jego upodobanie do światowych rozkoszy i i krótkowzroczne ich używanie, bez oglądania się na konsekwencje takiej postawy dla zbawienia. Aby uzmysłowić czytelnikowi, jak mało ma on czasu, by zatroszczyć się o uzyskanie życia wiecznego, jezuicki erudyta wprowadza do swego dzieła topos człowieka - „bańki na wodzie”, i słusznie wywodzi ten motyw od Warrona. Sam czlowiek to marność, „prawie nic, za śmiech poczytany":

Śmiechem zbiór ${ }^{24}$, śmiechem sława, śmiechem honor dany

Od świata, śmiechem życie, śmiechem są kłopoty

Podjęte bez bojaźni Bożej i bez cnoty.

Poemat Besseusza-Kuligowskiego jest dziełem o smutnej, sceptycznej wymowie. Jego polski tłumacz każe się śmiać z „ nietrwałej miłości rzeczy świata tego”, bo są one nic niewarte, ale w efekcie przedstawionych rozważań widać, że Demokryt chrześcijański płacze nad nędzą świata. Autor przekładu posługuje się bardzo ostrymi środkami wyrazu artystycznego (sięga między innymi w obrazowaniu po makabrę), aby z całą siłą unaocznić marność człowieka cielesnego. Na przykład paralelnie przedstawił opis zwłok dwojga kochanków, wykorzystując umiejętnie cały arsenał środków literackiego wyrazu dla zobrazowania procesu rozkładu ciał pięknych, młodych ludzi. Zwłoki kochanka znalazła „swawolna Małgorzata”, czyli kobieta swobodnego prowadzenia się, co potwierdza przysłowie „dobrze ojcu było z matką, dobrze też i mnie z Małgorzatką" ${ }^{25}$. Surowy moralista jezuicki informuje, że kobieta ta „stąd sławną w pokucie się

${ }^{24}$ Tu w znaczeniu: 'to, co zebrano w ciągu życia'; 'majątek'.

25 S. Adalberg, Ksiega przysłów, przypowieści i uyrażeń przysłowiowych polskich, Warszawa 1889-1894, s. 284. 
stała, że nagłą śmierć kochanka ujrzała”; straszny widok rozkładających się zwłok, opuchłych, brzydkich, cuchnących fetorem, otoczonych robactwem, ociekających ropą, skłonił grzesznicę do zmiany stylu życia. Jednak adresat dzieła Kuligowskiego nie jest traktowany wyrozumiale. Późnobarokowy wierszopis ostrzega:

A gdy wspomnisz, żeś jest gnój i lada godziny

Zostaniesz obrócony w proch od Prozerpiny,

Powściagniesz twe nałogi na grzech wyuzdane,

A rozkoszy będziesz mial za śmiech poczytane [s. 42].

Śmiech Demokryta chrześcijańskiego z tego świata jest okrutny — bardziej stosowny byłby tu płacz Heraklita nad tym grzesznym padołem, którego główny lokator, stworzony na obraz i podobieństwo Boga, ma pamiętać o śmierci, mieć świadomość, że jest tylko pielgrzymem na tej ziemi, a jego powłoka cielesna to kupa gnoju budzącego odrazę. Upodobanie w przedstawianiu scen makabrycznych ks. Kuligowski zapewne przejął za oryginałem. We Francji późnego średniowiecza, renesansu i baroku motywy makabryczne pojawiały się nader często w literaturze i malarstwie, zatem w sposób niemal naturalny przenikały do dzieł poświęconych tematyce śmierci, zmartwychwstania marności i nędzy czlowieka powstających w innych krajach katolickich, dzieł często po prostu tłumaczonych, poddawanych adaptacji ${ }^{26}$.

Jak widać, w dziele moralistyczno-satyrycznym - gdzie śmiech Demokryta pojawia się w tytule sformułowanym konceptystycznie, opartym na kalamburze, $z$ wyczuwalną intencją satyryczną - dominantą jest propagowanie ascetycznego modelu życia, odrzucenie powabów świata doczesnego, okazywanie mu pogardy. Ta w istocie nieśmieszna w swej wymowie książka o śmiesznym Demokrycie i jego śmiechu, gdy jako filozof uległ metamorfozie, głosząc w późnym baroku naukę o marności świata, nakazując jego odrzucenie, pokazując, że człowiek jest za śmiech poczytany, stanowi krańcowy etap rozwoju piśmiennictwa medytacyjnego, propagującego ascetyczny model życia, nawołującego do „wzgardzenia wszelkich próżności świata tego”.

W świetle tej wykładni czerpanie przyjemności z życia doczesnego, śmiech, żarty, wszelka rozrywka jest czymś bardzo niestosownym w ascetycznym modelu pobożności. Bowiem to, co czlowiek posiada na ziemi, jest bez wartości, a rozrywki oddalają go od Boga, zaś udział w nich często rodzi grzech. Trzeba odrzucić śmiech Demokryta, raczej należy się pogrążyć w placzu Heraklita, wywołanym refleksją nad nędzą kondycji ludzkiej.

Wielu było opiekunów duchowych, nadzorujących owe exercitia. Często wywodzili się ze środowiska jezuickiego, ale nie mniej często byli to franciszkanie, kartuzi, za-

${ }^{26}$ Zob. J. Delumeau, Grzech i strach..., op. cit., s. 134-137. 
konnicy innych zgromadzeń i kler diecezjalny ${ }^{27}$. Powstawały praktyczne podręczniki życia duchowego. Znany był w całej Europie traktat hiszpańskiego franciszkanina-obserwanta, Diega de Estella (1524-1578). Jego właściwe nazwisko to Diego Ballestros Crizas, pochodził z Nawarry, był kaznodzieją na dworze króla Filipa II. Jest autorem dzieła Libro de la vanidad del mundo (1562), książki bardzo popularnej w całej Europie. Miała ponad dwadzieścia wydań hiszpańskich i wiele przekładów, w tym często wznawiany włoski, łaciński, angielski, niemiecki, francuski i polski (w bibliografii literatury hiszpańskiej nienotowany) ${ }^{28}$. Polski przekład nie powstał z hiszpańskiego oryginału, lecz z tłumaczenia łacińskiego, które z kolei opracowano na podstawie wersji włoskiej, co autor translacji zaznaczył na karcie tytułowej:

Wielebnego w Bodze ojca i brata Dydaka Stellae, Hiszpana zakonu braci mniejszych Franciszka Świętego, których de observantia zową, O wzgardzie świata i próżności jego troje ksiag. Niedawno z hiszpańskiego języka na włoski przez Hieremiusza Foreste, a z wloskiego na laciński od wielebnego w Bodze ojca Piotra Burgunda Societatis Jesu, z łacińskiego, w Piśmie Świętym doktora, na ten czas kustosza gnieźnieńskiego braci mniejszych Franciszka świętego conventu nazwanych, pilnie przełożone, $z$ dozwoleństwem starszych.

Dwaj franciszkańscy pisarze: hiszpański twórca traktatu o wzgardzie świata i jego próżności oraz polski tłumacz tego dzieła, doskonale dopasowali się do ogólnoeuropejskiej tendencji do potępiania śmiechu i odrzucania rozrywek. Powstawały na ten temat utwory literackie. Międzynarodową karierę zrobiła Mowa w obronie Heraklita autorstwa portugalskiego jezuity Antonia Vieiry (1674). Powstała ona na potrzeby turnieju oratorskiego. Słynny kaznodzieja, obrońca Indian, głosił apologię łez Heraklita, zaś jego adwersarz, ojciec Cataneo, przemawiał za Demokrytem ${ }^{29}$. Świat, królestwo grzechu i szatana, miejsce niedoli, cierpienia, śmierci, zmusza człowieka do płaczu. Był on co prawda stworzony jako istota rozumna, szczęśliwa, skłonna do śmiechu. Odkąd jednak zgrzeszył, jest pogrążony w nieszczęściu i do radości życia nieskłonny. Bernardyn z Sieny, parafrazując słowa św. Hieronima, ujął to następująco: „Śmiać i radować się, patrząc na taki świat, nie jest sprawą człowieka rozumnego, ale szaleńca"30.

Sto lat przed wystąpieniem portugalskiego jezuity zabrał na ten temat głos hiszpański franciszkanin. Osobny rozdział swego traktatu poświęcił wywodowi o nik-

27 Zob. K. Górski, Kierownictwo duchowe w klasztorach żeńskich w Polsce XVI-XVII wieku. Teksty i komentarze, Warszawa 1980.

${ }^{28}$ Zob. D. J. Simon, Bibliografia de la literatura hispanica, t. 9, Madrid 1971.

${ }^{29}$ Pisał o tym Jean Delumeau, Grzech i strach..., op. cit., s. 647-650.

${ }^{30}$ Ibidem, s. 649. 
czemności żartów i śmiechu świeckiego. Brat Diego de Estella był surowym moralistą. Tłumaczył, ze pobożny chrześcijanin powinien odrzucić wszelkie rozrywki, idąc za głosem Ewangelii: „Biada wam, którzy się teraz śmiejecie, bo będziecie narzekać i płakać” (Łk 6, 25-26; tł. J. Wujek). Jeśli wierni opowiadają się po stronie światowych rozkoszy, w niebie będą wzgardzeni i opuszczeni. Zatem niech się strzegą ci, którzy na ziemi nie odpychają od siebie rozkoszy, albowiem w drodze do wieczności „ucisku wielkiego doznają".

Hiszpański mnich, gorący zwolennik ascezy, upatruje sensu życia doczesnego w ustawicznym umartwianiu się dobrych chrześcijan.

Błogosławiony to taki człowiek, który umartwionym będąc na tym świecie dla Chrystusa, mękę jego srogą sobie zawsze przed oczy przedkłada. Szczęśliwym to taki każdy, który na tym padole płaczu w smutkach jest ustawicznych. Wiele człowiek powinien płakać, wspomniawszy sobie o onym niebieskim Syjonie, wdzięcznej a przyrodzonej ojczyźnie swojej, bawiąc się tu teraz w Babilonie nikczemnego a przykrego świata tego [s. 62].

Franciszkanin-erudyta umiejętnie operuje argumentacją retoryczną, sięgając realiów biblijnych, znajdując tam tworzywo inwencyjne. Zastosowal tu topos z przeciwieństwa, a więc autentyczne zestawienie rzeczy po to, aby wyakcentować przedmiot perswazji. Niebieski Syjon przeciwstawiany jest Babilonowi. Syjon to według realiów ziemskich miejsce święte, wzgórze, na którym Salomon zbudowal świątynię. Babilon to największe miasto biblijnego świata, miejsce świeckich rozkoszy, posiadające pałac z wiszącymi ogrodami. Babilon, grzeszne miasto, było dwukrotnie pustoszone. Sacrum przeciwstawiono profanum ${ }^{31}$.

W duszy grzesznika rodzi się próżność i wszelkie moralne plugastwo, jeśli nie zapłacze on nad swą nieprawością. Trzeba więc plakać i zwalczać pożądliwość cielesną, hamować ciało i powściągać ziemskie namiętności, a wówczas „ziemia ciała płodna i obfita” będzie.

Diego de Estella i jego polski tłumacz uważają, że nikczemni są tacy ludzie, którzy chciwie zabiegają o bogactwo i inne światowe rozkosze, albowiem

próżność to jest wielka doczesnej a przemijającej pociechy szukać. Zatem lepiej i bardziej pożytecznie będzie w godzinie śmierci opłakiwać swe grzechy, niż mieć świadomość, ze żałuje się życia, które trawiło się na fałszywej i omylnej rozkoszy [s. 63].

Dalej następuje pouczenie, w którym karci się tych, którzy śmiech i radość życia przedkładają nad umartwianie się:

${ }^{31}$ Por. tom: Sacrum u' literaturze, red. J. Gotfryd, M. Jasińska-Wojtkowska, S. Sawicki, Lublin 1983. 
Bo jeśli tu na ziemi będziesz chciał go d ow a ć, wierz mi, na onym świecie g ł o d u dusznego zażyć musisz. Gdy się tu ustawicznie śmiać i weselić będziesz, po śmierci twej w piekle płakać musisz [s. 63; podkr. M. W.].

Zestawienie słów: „godować - głodować” nie jest przypadkowe. Tłumacz posłużył się kalamburem, igrając $z$ brzmieniowym podobieństwem tych wyrazów, wydobywając dzięki tej zabawie językowej moralistyczną naukę: jeśli tu na ziemi będzie z ciebie homo ludens, po śmierci będziesz łaknąć wartościowej strawy duchowej, którą wzgardziłeś w czasie, kiedy miałeś pracować na zbawienie. Kochański pragnął uatrakcyjnić lekturę swego tekstu, stąd próba wywołania efektu humorystycznego podbarwionego satyrą.

W obliczu śmierci grzesznik będzie musiał zapłacić wysoki rachunek za śmiech, który mu towarzyszył w życiu; ceną może okazać się wieczne potępienie. To bardzo gorzka przyjemność, która pociąga za sobą „karanie wieczne”. Choć chrześcijanin może żyć w przekonaniu, że wolno mu „bezpiecznie się weselić”, to będzie o wiele lepiej postępował, gdy weźmie pod uwagę, że w obliczu Boga będzie musiał uiścić zapłatę, i to znaczną, za sprawy i mowy swoje, związane z żartem i śmiechem.

Zamiast rozrywki franciszkański moralista zaleca częste i poważne rozmyślania o tym, żeby „ostrzej żywot swój prowadzić”, a więc pokutować, wyobrażać sobie męki piekielne, które mogą być udziałem miłośników „rozkoszy i żartów”. Ludzie pobożni i święci kierują się w swym postępowaniu słowami Hioba $(3,24)$ „Przed tym, niż pokarm wziąć mam, wzdycham” [s. 63]. Natomiast „rozkosznicy świata” mają dobrze i przyjemnie, weselą się przy muzyce, nie mając świadomości, że krok po kroku „do piekłów wstępują", krocząc drogą zażywania świeckich uciech. Bowiem „ten jest koniec rozkoszy i próżnej chwały świata tego" - pouczają dwaj franciszkanie, i dodają, nawiązując do obiegowej wówczas opinii:

Nie czytamy w Piśmie, aby się kiedy Chrystus śmiać mial, ale czytamy, iż często płakał. Płakał przy narodzeniu swym, płakał przy wskrzeszeniu Łazarza, płakał nad onym miastem Jerozolimskim, płakał na krzyżu. A co więtsza, wszytko życie jego na świecie płacz był i pokuta ustawiczna [s. 64].

Tłumacz, pisarz dobrze obeznany z retoryką, wykorzystał tu perswazję nakłaniającą, pragnąc przekonać jak największą liczbę czytelników do idei wyłożonej w swoim dziele. Świadomie stosowal takie figury retoryczne, które umożliwią calkowite przekonanie odbiorcy, doprowadzenie do tego, aby przyjął on przyjęty przez autora cel perswazji. Perswazja nakłaniająca wspiera się pouczeniami dydaktycznymi. Jej podstawą jest autorytet moralny i odpowiedni poziom intelektualny tego, kto naucza. Kochański zastosował tutaj symploke, figurę stanowiącą połączenie anafory z epiforą, usytuował tę figurę w miejscu zawierającym bardzo ważny punkt perswazji. Kaznodzieja dowodzil, że Chrystus nigdy się nie śmiał, bo jego życie wypełniał płacz nad grzechami 
ludzkości i nieustająca pokuta. W perswazji autor odwoływał się do najprostszych, oczywistych doświadczeń czlowieka:

Jeśli się nie staniecie jako ci maluczcy, nie wnidziecie do Królestwa niebieskiego. Dziecię, małe niemowiątko, obrony inszej nie ma, jeno łzy a płacz. I ty się też tym broń, radzęć, od najazdów szatańskich [s. 64-65].

To sentencyjne pouczenie wsparte jest przywołaniem szeregu egzemplów, mających stanowić dowody jego wiarygodności, aby autor przekonał do końca czytelnika, czyli osiągnął cel dydaktyczny swej perswazji: aby pobożny chrześcijanin w pełni zaakceptował głoszoną w traktacie naukę, jej znaczenie religijne i wymowę moralną. W tym przypadku egzempla nie są rozbudowane, najczęściej sprowadzają się do wspominania osób lub zdarzeń, opisanych w Biblii. Cały wywód ma bardzo przejrzystą wymowę o charakterze moralizatorskim, ale mimo to na samym końcu rozdziału autor umieścił rekapitulację pouczeń stanowiących wykładnię, precyzyjnie sformułowane wskazówki, jak należy postępować:

Lepiej być utrapionym z ludźmi sprawiedliwymi niźli weseląc się, chleba zażywać z grzesznymi. Lepiej płakać na puszczy, niźli się w pałacach kosztownych książęcych weselić. Pogardzajże tedy tą rozkoszą doczesną, abyś na potym odniósł chwałę wiekuistą [s. 65].

Moralistyczno-wychowawcza funkcja egzemplum w pełni została tu przez autora wykorzystana. Ostatnie zdanie stanowi tranzycję do kolejnego tematu.

Śmiech i rozrywka to uczestnictwo w rozkoszy świeckiej, a ta powinna być wyeliminowana z życia pobożnego chrześcijanina — naucza po polsku ojciec Diego Estella. Łzy Heraklita towarzyszą czlowiekowi przez cały czas ziemskiej wędrówki, i to jest właściwa droga chrześcijanina do zbawienia. Autor traktatu sformułowal skierowaną wprost do czytelnika refleksję:

Narodziłeś się płacząc, umierasz też z płaczem, a gdy chcesz żyć w śmiechu i w weselu żywot twój prowadzić, wierz mi, iż wtenczas nie chodzisz drogą ludzi sprawiedliwych [s. 67].

Fray Diego tłumaczy, że mieszkamy w ciemnościach tego świata. Wielką niestosownością jest życzyć sobie wesela, rozrywki. Stąpamy w ciemnościach, bo lepiej, żebyśmy nie byli świadomi, co nam wolno, a czego nie wolno, „tak, iż w tym sami siebie nie poznawamy", bo jeśli nie wiemy, czy jesteśmy na dobrej, czy na złej drodze, to nie mamy powodu do radości. Błądzimy. Hiszpański kaznodzieja i jego polski tłumacz raz po raz przypominają, że „próżność to jest, gdy jakiej człowiek szuka rozkoszy w tym stanie niebezpiecznym, z którego może być dla niej strącony do piekla" [s. 66]. Trzeba umieć wieść swe życie między nadzieją a bojaźnią. Co prawda grzeszni ludzie zachowują we- 
sołość, mimo że chodzą w ciemności i nie znają drogi, ale to niewłaściwa postawa. Czas życia doczesnego to czas pokuty, zatem nie należy go spędzać na świeckich rozkoszach. Wokoło umierają ludzie, każdy zetknął się ze śmiercią i miał sposobność snuć o niej stosowną refleksję —że śmierć spotka każdego i że jest „wątpliwy stan życia” człowieka. Autor poradnika dla grzeszników uświadamia ludziom ważne powody, ukazuje, jak niestosowny w życiu jest śmiech:

Barzoś marnym i nikczemnym, jeśliś zabaczył bojaźni Bożej, trawiąc czas swój na śmiechu i rozkoszy świeckiej. Więcej się ociec ten frasuje niźli weseli, który widzi narodzonego syna swego zaraz i umierającego. Krótka to rozkosz świata tego - mówi mędrzec. Niemądry to, co się z głupstwa swego chwali i w nim kocha. A próżna to zaiste rzecz, gdy kto pragnie nasycić serce swe tymi świeckimi rozkoszami, których gdy ledwie używać pocznie, zaraz giną i ustają [s. 66];

Barzoś jest nikczemnym i podobnym niememu stworzeniu, gdy się kochasz i chełpisz z tych rzeczy świeckich, ponieważ ci śmierć jest nade wszystko bliższą i pewniejszą [s. 67].

Przychodząc na świat, rozpoczynamy swą drogę życiową, a w chwili śmierci kończymy to pielgrzymstwo. Zatem kaznodzieja udziela kilku prostych rad na tę drogę ku śmierci, a także i ku zbawieniu. Ujęte są w formę komunikatywnych pouczeń:

— nie staraj się usilnie o zdobycie bogactw;

— nie buduj drogich, ogromnych i luksusowych pałaców, bo po śmierci domem twoim będzie grób „ciasny i maluczki”;

— nie staraj się zostać człowiekiem wybitnym;

— pamiętaj, że modliłeś się jako małe, nędzne, mizerne dzieciątko i zważaj na to, abyś był pokorny w chwili śmierci i po zgonie;

— skoroś ubogo i cicho przyszedl na świat, nie stawaj się panem ani potentatem, „żyjże tu na świecie w pokoju” [s. 68].

Zakończenie rozdziału zawiera serię pouczeń, ujętych w formie wyliczenia:

Nie miłuj ani się kochaj w tych bogactwach świata tego, nie szukaj godności nikczemnych, nie traw czasu twego próżno na rozkoszach i weselu świeckim, bo to wszytko próżność jest, ale staraj się, jakobyś grzechy twoje oplakiwal, pokutuj na tym nędznym świecie, abyś mógł dostąpić nieba [s. 68];

Zakochaj się w serdecznej skrusze i pokucie świeckiej. Pospieszaj się do onej wiekuistej ojczyzny, a to wygnanie ziemskie niech ci będzie za raj 
i rozkosz wieczną. Bo by źle było z tobą, wierz mi, i barzo byś zabłądzil, gdybyś tu zawsze myślił żyć w rozkoszy [s. 69].

Mamy do czynienia z perswazją pobudzającą do działania. Kaznodzieja sugestywnie i autorytatywnie przekonuje czytelnika do idei wzgardy świata, siłą perswazji chce go poruszyć i nakłonić do poglądu prezentowanego w dziele, spowodować zmianę stylu życia i systemu wartości dotychczasowego grzesznika, namówić do troski o zbawienie, do życia pobożnego w pokorze i pokucie, z myślą o śmierci. Diego de Estella, dobrze obznajomiony z retoryką, umie skutecznie przekonywać odbiorców swego dzieła, pobudzić ich do aktywności w odrzuceniu „próżnej rozkoszy świeckiej”, do płaczu nad nędzą grzesznego człowieka.

Czy w tym smutnym nauczaniu hiszpańskiego franciszkanina jest miejsce na rozmowy o śmiechu, jeśli miałby to być śmiech Demokryta chrześcijańskiego?

Skoro Fray Diego odradza żarty, śmiech i wykazuje próżność rozkoszy świeckich, to w końcu udziela rady na temat „W czym się nabarziej czlowiek na świecie ma kochać”.

Posługując się cytatem z Ewangelii św. Jana (16,20-21): „Weselcie się w Panie i drugi raz mówię, weselcie się", doradza, aby znajdować radość w miłości Boga. Nie trzeba się zresztą posuwać do skrajności i uważać, że Stwórca oczekuje od człowieka, aby ten zawsze płakał i smucił się. Wręcz przeciwnie, żąda tylko, aby zmienić swą radość na taką, która jest wieczna, a wynika z „dobrego sumienia”: „Pan nie każdego wesela i radości gani i zakazuje, jeno fałszywego, świeckiego i zdradliwego”. Dobre, spokojne sumienie jest porównane do prawdziwego, wiekuistego wesela, które czeka na pobożnego człowieka w niebie. Swoim zwyczajem, hiszpański franciszkanin, mając na celu dydaktyzm wypowiedzi i skuteczność perswazji, zawartej w objaśnionym rozdziale, sięgnął po egzempla; tym razem ich źródłem jest wyłącznie Biblia. Konkluzja z omówionych przykladów jest bardzo prosta:

Bo gdzie Boga nie masz, tam niepodobna rzecz, aby bezpieczne wesele być miało. Radość ludzi świeckich, gdy się w złym weselą, nie jest prawdziwa, bo nie sadzi się na sumnieniu bezpiecznym. Święty Jan Chrzciciel radował się w żywocie matki swojej, która radość słuszna była. Ale taka radość jest nikczemna, która za fundament nie ma laski Bożej. Starajże się o łaskę Bożą, a prawdziwe wesele otrzymasz [s. 70].

Znakomicie obeznany z zasadami retoryki pisarz-kaznodzieja po egzemplach wprowadzil szereg pytań retorycznych, potwierdzających postawioną na początku rozdziału tezę, aby wyrzec się wszelkiej radości doczesnej na rzecz wesela niebieskiego. Większą wartość ma jedna minuta „pociechy duchowej” niż „wszytkie wesela tego świata” [s. 71]:

Wszelkie to doczesne wesele za krótki czas niszczeje. [...] Te świeckie uciechy barzo prędko opuszczają złe ludzie, ale pociechy sprawiedliwych są pel- 
ne źrzódła wód żywych, nigdy nieustawających. A tak ta radość i wesele jest napewniejsza (mówi Pan), którego żaden od was nie oddali [s. 71].

Jednak na świecie jest wielu takich, którzy chwalą się bogactwami, są ogromnie przywiązani do dóbr doczesnych, które zgromadzili. Ich siła leży w bogactwie; jeśli zostaną go pozbawieni, nie mają się czym poszczycić. Kochamy się w rzeczach materialnych, budzą one w nas żądze i chciwość, nigdy nie możemy doznać pełnego zaspokojenia, pragniemy coraz więcej bogactw i dostatku. Doczesne wesele i radość idą w parze z pożądaniem tych dóbr. Kaznodzieja, nauczyciel pobożnej medytacji uświadamia, że nie znajdzie się w nich równowagi duchowej i doskonałego spokoju. Prawdziwą radość odnajdujemy w Bogu. Jest ona wówczas nieskończona i absolutna. Dlatego fray Diego przekonuje, że "tam będzie wtenczas zupełne wesele i pokój, gdzie żadnej rzeczy więcej pragnąć nie będziemy” [s. 72]. Mówi „o nietrwałej miłości rzeczy świata tego" — by użyć słów Sępa-Szarzyńskiego. I tak jak autor Rytmów konkluduje:

Ale iż Bóg sam jest, który napełnia i nasyca żądze nasze, przeto On sam też ma być słusznie miłowany, abyśmy dostąpili wesela prawdziwego. Mówi prorok Dawid, że sam Pan Bóg z dobroci swojej napełnia żądze nasze. [...] Owa, krótko mówiąc, ponieważ tego świata wesele i radość nikczemna jest, w samym się tedy Panu Bogu weselić mamy [s. 72].

Tak więc Diego de Estella wskazał franciszkańską drogę do radości chrześcijanina odrzucającego nikczemne świeckie żarty i śmiech, nikczemne wesele i radość tego świata. Radość ta oparta jest na wyzwoleniu się z niewoli dóbr materialnych, na miłości do Boga, na odnowieniu człowieka poprzez miłość do Chrystusa i naśladowanie go, na budowaniu więzi człowieka z tym, który z miłości dla nas dał się ukrzyżować. „Wartości, które były wartościami Chrystusa, uczynić swoimi własnymi wartościami"32. Obok odrzucenia bogactw, radości duchowej dostarcza modlitwa, czyste serce. To także uzyskanie spokoju wewnętrznego, o którym mówił św. Augustyn:

Dla siebie nas, Boże, stworzyłeś i niespokojne jest serce nasze, dopóki nie spocznie w Tobie ${ }^{33}$.

Z wykładu fray Diega wynika, że

istotą doskonałości chrześcijańskiej jest miłość, będąca doskonałą mądrością, z którą związane są łaski mistyczne, kontemplacja jest doskonaleniem miłości, a miłość jest bardziej doświadczeniem Boga niż wizjąa34.

\footnotetext{
32 J. Tischner, Mitość niemiłowana, opr. S. Grotomirski, Kraków 1993, s. 9.

${ }_{33}$ Św. Augustyn, Wyznania, tł. Z. Kubiak, Warszawa 1982 (I 1).

${ }^{34}$ J. Aumann, Zarys historii duchowości, tł. J. Machniak, Kielce 1993.
} 
Zadaniem medytującego chrześcijanina jest pielgrzymowanie umystu do Boga, jak to ujął teolog franciszkański, św. Bonawentura, w tytule jednego z głównych swoich dzieł. Doktryna wypracowana przez ojca serafickiego, św. Franciszka i teologów jego zakonu, piszących w następnych pokoleniach, jest wyraźnie podbudowana myślą św. Augustyna. Dlatego mimo akceptacji ascezy, życia w „ostrości” zasad, surowości i pokucie, jest jednak przyjazna grzesznikowi, który otrzyma pouczenie, jaką drogę ma obrać, aby uzyskać zbawienie, spokój duszy, zjednoczenie z Bogiem poprzez miłość.

W duchowości Europy chrześcijańskiej od wczesnego średniowiecza po późny barok w piśmiennictwie ascetyczno-medytacyjnym spotykamy strumienie łez Heraklita, opłakującego nędzę, marność i upadek człowieka. Dzieła podejmujące tę tematykę po większej części przesiąknięte są skrajnym pesymizmem, człowiek jest opanowany przez grzech, pozbawiony szans na zbawienie. Jednak, mimo ogólnego kierunku w oficjalnej nauce Kościoła, głoszącego upadek człowieka, roztaczającego straszliwą wizję cierpień piekielnych grzeszników, pojawiają się w tejże nauce nurty bardziej przyjazne człowiekowi, który nie musi ciągle płakać nad swoją marnością, ale przeżywać radość życia, radość istnienia, radość miłości do Boga i bliźniego, również do tego najsłabszego i najbiedniejszego. Kochając, dajesz miłość i chcesz miłości - rozumowali współbracia świętego Franciszka. Po wiekach wybitny przedstawiciel tego zakonu, fray Diego de Estella, mimo ogólnej aprobaty dla powszechnie wówczas głoszonej i przyjmowanej w nauce Kościoła idei pogardy świata i nędzy człowieka, znalazł takie argumenty, takie nisze w rozumowaniu o drodze grzesznika do Boga, które pozwalały spojrzeć temuż chrześcijaninowi z optymizmem na perspektywę zbawienia, a w życiu doczesnym dostrzec też czasem miejsce na śmiech, pod warunkiem, że jest to śmiech Demokryta chrześcijańskiego. 